\title{
The story and conservation problems of an industrial heritage building in Istanbul: the Sütlüce Slaughterhouse
}

\author{
S. G. Kucuk \\ Department of Architectural Restoration, \\ Mimar Sinan Fine Arts University, Turkey
}

\begin{abstract}
The slaughtering process had been a serious issue throughout the centuries in Istanbul due to the lack of proper facilities for handling livestock. While streets may be alternative locations for this process, it was not favourable because of the unhygienic conditions of such venues. Tophane slaughterhouses are one of the places which were built between narrow streets by the Bosporus to meet this need. The location of the Tophane slaughterhouses can be seen on the map drawn in 1905 by the French cartographer, Charles Edouard Goad. Interestingly, the stages of the meat slaughtering process can be reasonably mapped out from the names of the streets, city-wall gates and ports around the Tophane neighbourhood. With the construction of a new facility known as Sütlüce Slaughterhouse by the Golden Horn in 1923, all slaughterhouses were gathered into one central building. Being the first contemporary slaughterhouse in Turkey, The Sütlüce Slaughterhouse became a symbol of modernization. In this study, industrialization efforts of Istanbul in the $20^{\text {th }}$ century will be presented by analysing the evolution of meat industry.

Keywords: Tophane, Sütlüce, Karaagac, slaughterhouse, industrial heritage, meat butchering process.
\end{abstract}

\section{Introduction}

During the Ottoman age, one of the issues on which the administration focused most was how to fulfil the meat demand of Istanbul city. Since animal meat transported from remote regions became spoiled on the way to Istanbul due to the unfavourable conditions of the age, the slaughtering process of meat production 
was largely conducted within the city centre, which inevitably fuelled a number of health and hygiene problems within the city. It has been reported that the earliest slaughterhouses after the conquest of Istanbul were placed on the peripheries of Yedikule. Because Yedikule slaughterhouses were located so far from the city centre, Ottoman butchers filed complaints in the 1780s and demanded that the old slaughterhouses in the city centre be reopened. This lead to the operation of private slaughterhouses in the city centre [1]. It is thus the focal point of the present study to analyse the transformation triggered by one of these slaughterhouses, Tophane slaughterhouse, and its surroundings [2]. The stages followed during the meat slaughtering process in Tophane slaughterhouses can reasonably be tracked from the street names, city-wall doors and port names. To illustrate; one street is named Tabakhane to refer to tanneries in which skins were processed whilst another street is named Kireç Kuyusu as a reminder of the lime pits used during this process. The process of changing street names has been unearthed by referring to the 1988 book of Armenian historian Kömürciyan [3] on $17^{\text {th }}$-century Istanbul, the D'Ostoya map [4] dated to 1858-1860, the Goad map [5] dated to 1905, the Pervititch map [6] dated to 1927-1928 and the Suat Nirven map [7] dated to 19481949.

As seen in the 1905 Goad map, as well as slaughterhouses, barns and ice stores had expanded to a remarkably large area indicating how deeply significant Tophane slaughterhouses were in the area. In the present study that employed old photographs, reports and newspaper articles, the transformation process of the Tophane slaughterhouses, which were randomly scattered and rarely favoured in the city centre, into the Sütlüce Slaughterhouse (which stands out as the very first central slaughterhouse of the Republican age and is acclaimed as the first establishment ever preserving the world's first urban biological water treatment facility) has been analysed [8]. The other issues investigated are industrial sites forming Sütlüce Slaughterhouse and their capacities; architectural features of the structure and how, in the end, this industrial structure was demolished on account of its polluting effects in Golden Horn and replaced with a replica to be allegedly "re-functionalized". By referring to this particular slaughterhouse, it is thus the aim of the current research to illustrate Istanbul's attempts at industrialization in the $20^{\text {th }}$ century.

\section{Meat procurement in the Ottoman age}

Meat has always constituted a noteworthy place in the diet of Istanbul and meat supply to the city has always been one of the primary tasks. Under the unfavourable conditions of the particular age, it was unfeasible to transport to Istanbul the animals slaughtered in the remote areas away from the city without them getting spoiled. For that matter, the slaughtering process was sometimes completed right outside the city walls or on certain occasions conducted in the special locations allotted in the city centre for this particular process. Except for sacrificial animals, no live animal could be sold to ordinary citizens for slaughtering purposes and the public were prohibited from slaughtering animals wherever they wanted except on Muslims' sacrifice holiday. Yet unlicensed 
butchering was still a common practice as it was in all ages but it was, theoretically, legally prohibited and subject to punishment. As slaughterhouses were filthy and insanitary places spreading bad odours, particular attention was paid to building these places as distant from the city centre and residences as possible [1].

It is reported that the earliest slaughterhouses upon the conquest of Istanbul were located outside Yedikule. Following the conquest, tanneries and leather shops were grouped in Kazlıçeşme, near Yedikule, where slaughterhouses were constructed. Until recently, it had been a traditional practice to operate near the slaughterhouses the kind of businesses such as tanneries, kirish houses, and wax houses that used the remaining parts like skin, intestines and tallow of the slaughtered animal as raw material.

In the $17^{\text {th }}$ century, slaughterhouses that were scattered in different parts of the city were all designated to be relocated in Kazlıçeşme in Yedikule. The main slaughterhouse in 1780s-Istanbul was located in Yedikule. Yedikule slaughterhouse was situated on a plateau near the sea and away from the city centre. There were a number of small slaughterhouses in several parts of the city earlier, but the centre of animal slaughtering was the outskirts of Yedikule. It was a full-scale ceremony to transport meat from Yedikule slaughterhouses to Etmeydan1 (Meat Square). In the 1780s, butchers demanding the old slaughterhouses in Istanbul and Eyüp neighbourhoods be reopened filed a complaint due to the remoteness of Yedikule slaughterhouses. As a result, the slaughters that were already practiced occasionally in the city centre once again became widespread [1]. In Istanbul at the end of $18^{\text {th }}$ century, aside from Yedikule, there were slaughtering locations in Eğrikap1, Balat, Kasımpaşa, Eminönü, Balıkpazarı, Hasır İskelesi, Yenikapı, Üsküdar and Tophane. In the city centre, a slaughterhouse equally as important as Yedikule was Tophane slaughterhouse.

\section{Tophane slaughterhouses}

\subsection{Location and history}

Tophane slaughterhouses were located in the Tophane region inside IstanbulGalata. This region has always been historically-renowned by virtue of encompassing certain parts of the Galata walls that were already present in the $15^{\text {th }}$ century. The Galata walls located in Kemeralt1 region close to Tophane were, as reported in the inscription on Mumhane Gate, erected in May 1446 by Genovese commander Marrufus Baldasar [9]. On the walls around Tophane the names (Mumhane and Kireç Kapısı) of the gates opened to allow partial access are reminiscent of the slaughtering process, which invokes the idea that there was already slaughtering in process here in the $15^{\text {th }}$ century. Nonetheless, there are no definite data on the date that those wall gates acquired these names. Still, Armenian historian Kömürciyan [3] when depicting $17^{\text {th }}$-century Istanbul identified the names of wall gates. Kömürciyan explained in his work that between Kireç Kapısı (Lime Gate), one of the Galata wall gates around Tophane, and Kılıç Ali Paşa Mosque there used to exist tanneries in which pelts were treated and at 
nearby Mumhane (Wax House) Gate, wax was manufactured by rendering animal fat. It is also known that during the very same age Tabakhane (Tannery) and Sirkeci ports were located in the sea and ferries transporting ship timber from Black Sea used to anchor here [10]. With the erection of a pier in the $19^{\text {th }}$ century these ports were toppled.

The walls and gates opening to the street can easily be seen from the 1858dated d'Ostoya map, figure 1. It is noteworthy that the gates of the walls in Mumhane Street were named the same in the $19^{\text {th }}$ century as in the $17^{\text {th }}$ century. Besides, the streets these gates opened onto were also namesakes with wall gates as Mumhane Kapısı Street and Kireç Kapısı Street. In this map, Tabakhane Street near Kireç Kapısı Street is also worthy of notice. The pier was not yet erected when this map was drawn.

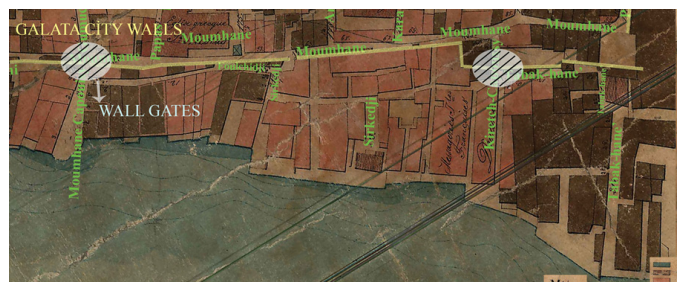

Figure 1: Galata city walls, gates and streets are in d'Ostoya Map.

The Goad map, drawn in 1905 by French cartographer Charles Edouard Goad for insurance purposes, mapped the region in detail and it is possible to locate on the map the functions of buildings, numbers of floors and construction materials used. In this map it is detected that a number of functions related to meat butchering are collected in one region as indicated on the map by Goad himself, see figure 2. Before touching on these procedures, the stages that make up meat the butchering process shall be briefly defined.

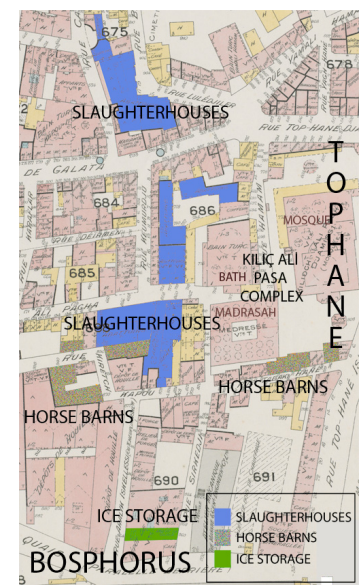

Figure 2: $\quad$ Butchering process in Goad map. 
To start the meat butchering process, the first stage is providing barns to shelter the animals. The butchering process must be performed by competent people in hygienic places. Following the butchering process, the place should be cleansed, dripping blood should be accumulated in a particular place, covered and treated with lime, and putrefaction must be prevented and covered with soil. To prevent putrefaction, the obtained meat should be kept cold in large freezers or if not available, in ice boxes. To remove hair from skin it should be tanned in tanneries. In the next stage, skin must be appropriately preserved after salting [11]. The remaining tallow could be manipulated as wax if there is a mill in the vicinity.

The Goad map shows that there are around ten, two-floor masonry slaughterhouses in Tophane and that nearby there is a one-floor wooden slaughterhouse, five barns and one ice house. For storing ice, no detached building was constructed but one of the basements is used as a store. Although there were no city walls at the onset of the $20^{\text {th }}$ century, Kireç Kapısı and Tabakhane Streets keep their names up to date. In the 1927-dated Pervititch map, too, the streets preserve their names while in the 1949-dated Suat Nirven map Kireç Kapısı (Lime Gate) Street turned into Kireç Kuyusu (Lime Pit) Street and Tabakhane Street was named as Murakip Street. By 1949, the reflection of the meat butchering process in street names became less popular and currently there is almost no trace of this practice since slaughterhouses in the region were cleared away in 1923 and united under a new slaughterhouse in Sütlüce. However, Tophane slaughterhouses remained in the region for a very long time almost like a building complex.

\subsection{The problems of Tophane slaughterhouses}

Tophane slaughterhouses were frequently a source of complaint due to spreading bad odours, polluting the environment and spreading diseases. During the transmission of imported animals to slaughterhouses they had to pass through the most crowded and narrowest streets between Tophane and Galata, which blocked traffic flow and limited available walking space, as seen in figure 3 [12]. Along the busy streets filled with trams, cars and pedestrians shepherds with dirty sticks they hurled around polluted the atmosphere and disturbed the citizens with their cries to control the animals. Run-away bulls injured pedestrians and were slaughtered on the spot they were caught [13]. After the butchering process in slaughterhouses or on the street, streets were soaked with blood and meat parts were scattered around. Additionally, there was no supervision in slaughterhouses, which fuelled the butchering of sick animals [14], and in turn the consumption of bad meat became an unpreventable problem.

Like the Tophane slaughterhouse, unfavourable substructure conditions in several private slaughterhouses in and around the city centre, inadequate numbers of barns to shelter the animals and unsupervised conditions of the butchering process necessitated the establishment of a modern public slaughterhouse [15]. Nonetheless, this idea received different reactions from different sets of society putting forward two opposing views. Advocates of the first view opposed this initiative by claiming the continuity of traditional practice or simply due to their pure personal interests. The other group emphasized the necessity to establish 


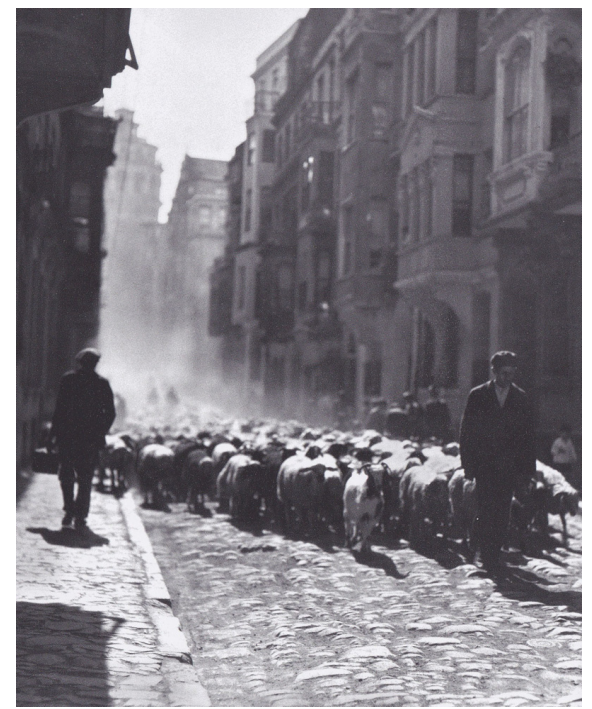

Figure 3: $\quad$ Sheep on Galata streets 1928 [12].

modern institutions as required by the current scientific and technical advances. The ones advocating the establishment of a public slaughterhouse argued that this was also a necessity for a cleaner city [15].

\section{The measurements taken against private slaughterhouses in Ottoman state, enacted laws}

Having considered all these problems about private slaughterhouses the Ottoman state attempted to take immediate measures. In order to prevent their emergence, II Mustafa enacted a firman in 1698 but during the regression period of the Empire, these laws were no longer strictly adhered to. With the proclamation of Tanzimat in 1839, a new age when anyone interested was free to open a butcher shop and cut the animal in the back yard of their shop was initiated [16]. The idea to close down private slaughterhouses and replace them with a modern public slaughterhouse was introduced during Ottoman Emperor II Abdülhamit's reign (1876-1909). The October 5, 1877 "Dersaadet (Gate of Bliss) Municipality Law" introduced a number of new regulations on public health, including the inspection of meat and improved butchering conditions and it was envisaged to perform the slaughtering process in slaughterhouses commissioned by municipalities, but the law could not be put into practice [17]. As the calendar turned to the 20th century, Cemil Topuzlu's extensive research on this topic gathered attention. Having endorsed major projects for Istanbul, Operator Cemil Topuzlu was appointed to the position of Şehremin (Mayor) in 1912. Cemil Topuzlu initiated an international project contest to meet Istanbul's requirement for a modern slaughterhouse and to answer all the needs to meet this objective. Six foreign companies bid in the contest. At the end of the negotiations conducted by the commission, Paris 
slaughterhouses' general director M. Emille Camus's bid offered by the company he represented won the contract [16]. However, because of a number of bureaucratic deficiencies and opposition from the Provincial Council, the project was delayed and with the outbreak of the First World War (1914-1918) the project was annulled completely. In the aftermath of the First World War, the idea to erect a common slaughterhouse was reintroduced and for the Şehremini Cemil Topuzlu slaughterhouse initiative, Umur-1 Mimariye (Public Architecture) branch manager Selahaddin Bey and architect Vedat Tek were asked to concoct a project. Of the two projects Vedat Tek's plan was approved [13]. (Some resources refer to Ahmed Burhaneddin, Osman Fitri and Makro Logos as the architects of the structure [18]). Following long disputes the foundation of Karaağaç Slaughterhouse was laid on 27 November 1919 and opened on 12 July 1923 [13].

\section{Sütlüce Slaughterhouse}

\subsection{Location and name of the place}

Sütlüce Slaughterhouse is located in Karaağaç Street on the Beyoğlu shore of Istanbul, Golden Horn (figure 4), thus it is known as Karaağaç Slaughterhouse in a number of resources. However, the origins of the Sütlüce term reflected in the district name are uncertain. Sources reveal that Byzantines used to call this place "Galatyani". A number of historians attribute this word to "galatea" meaning "milk" in Romaic language [20], and relate its origin to the dairies located here during the Byzantium era [1]. $17^{\text {th }}$-century traveller Evliya Çelebi stated that the name of the region derived from "milk" in Arabic, Romaic and Turkish languages as can be explained by the purity of milk attached to the purity of vegetation and climate [20].

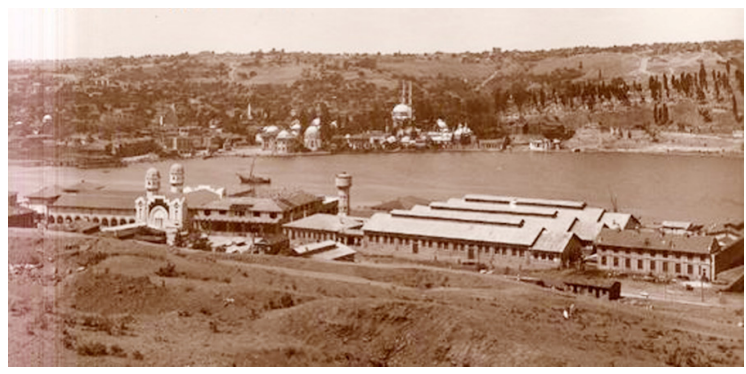

Figure 4: Sütlüce Slaughterhouse in 1930s. Three slaughtering pavilions at the right and ice plant building with two towers are at the left side [16].

\subsection{Spatial and architectural features of slaughterhouse}

In the facility there existed three slaughtering pavilions each spreading to a $1000 \mathrm{~m}^{2}$ area to contain four barns that enabled butchering 1500-2000 sheep and goats and 250-300 cattle per day, water pumps, pump machinery buildings, and a coffee house and cafeteria [16], see figures 4 and 5. 


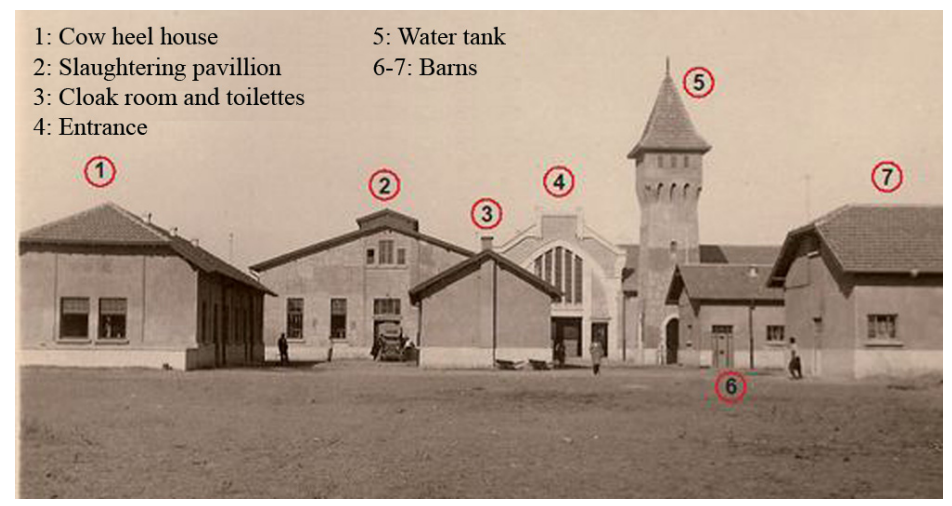

Figure 5: Buildings of the slaughterhouse [16].

Slaughtering pavilions situated parallel to the shore, were consisted of three rectangle blocks with the dimensions of $72 \mathrm{~m}$ x $20 \mathrm{~m}$. Inside, there was a $12.7 \mathrm{~m}$ wide mezzanine which centres $7.1 \mathrm{~m}$ height internal volume. In reinforced concrete structure, columns were tied with gousset beams. The roof which was carried with I and U profiled trusses was lifted through the ridge so, the ventilation and lighting inside were ensured. On the facades for decorating, cement plastered surfaces were lined and column rows were adapted to the facade as engaged columns [19], see figure 6.
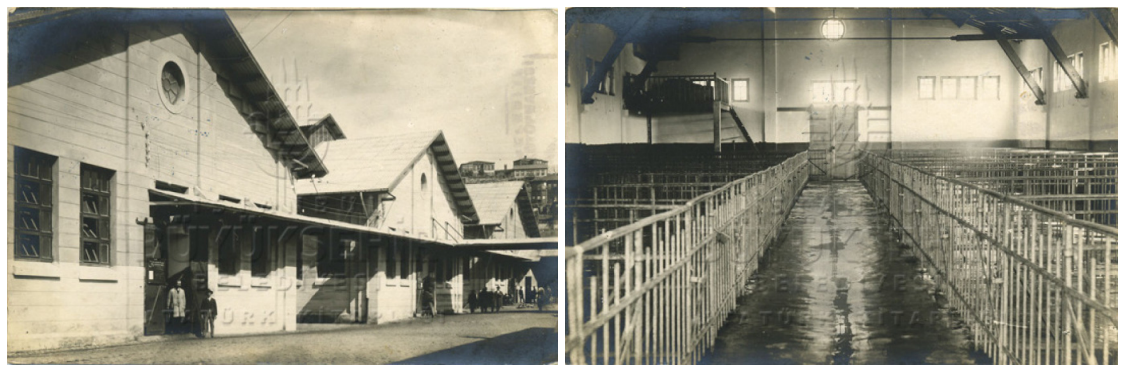

Figure 6: Slaughtering pavilions; façades on the left and interior at the right side.

In the immediate aftermath of opening ceremony, Professor Hulki Erem and Şehremaneti (Constabulary) Veterinary Manager Esat Evsen were dispatched to Europe to investigate European slaughterhouses and upon their return, cold storage facilities and - ice plants, livestock market and share division, meat-sale hall and administration building, tripe, feet and bowel cleaning locations, autopsy hall, an oven and similar units were added to the slaughterhouse [16].

Cold storage facilities and ice plant with the capacity of manufacturing 50 tonnes of ice per day were put into operation on 20 July 1925 by Şehremini Operator Emin Bey [16]. The most distinguishing building of the Sütlüce Slaughterhouse is its tower ice plant building, in figure 7 . This building with its 
symmetrical face pattern, lancet windows, roof parapet downgrading in echelon and its divisions covered with blue tiles between pointed arches aptly reflects the style of the First National Architecture of its age [18]. In 1929, an additional facility manufacturing 25 tonnes of ice and a second one producing 50 tonnes of ice were added [16]. Steel structures and bricks or tiles used in the construction of the slaughterhouse were imported [18].
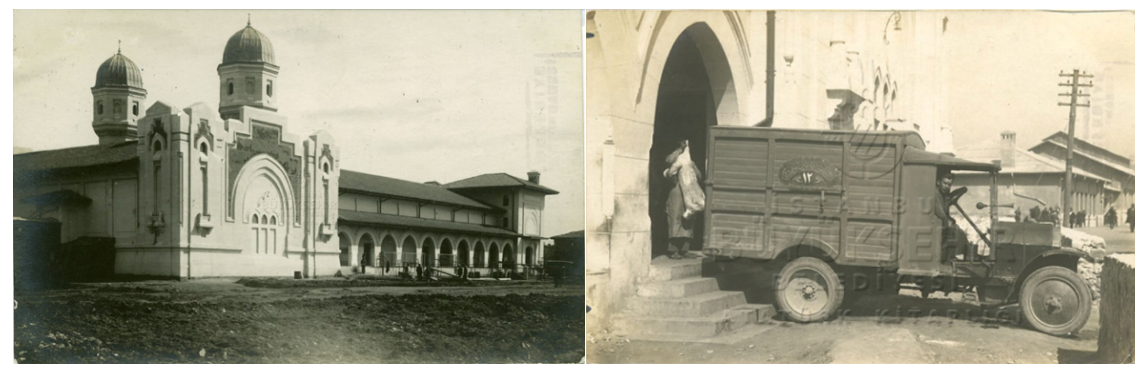

Figure 7: Ice plant building (at the left) and the trucks carrying meat from there [21].

Erecting the meat-sharing house, which was another part of slaughterhouse complex, was initiated in 1924 and completed in 1929. Meat sale hall and administration building were finalized in 1931 [16]. Additionally, the construction work of the bowel unit was assigned to a Russian fugitive contractor, Ferdman, in 1924 for a term of 10 years within the scope of the "build-operate-transfer" model; paçahane (feet house) construction was transferred to another contractor in 1926 within the scope of the same model.

When the construction of all these facilities was completed, Sütlüce Slaughterhouse, including its meat-sharing facility, spread over 20 thousand square meters closed, and 31 thousand square meters open totalling 51 thousand square meters usage area, 80 tonnes of first meat cold storage plants conserving $300-350$ cattle, $3-4$ thousand sheep and goats, ice stores producing 100-125 tonnes of ice daily and preserving the same amounts of meat per day, 1200 cases of egg conservation storage and four large stores preserving a variety of food stuffs [16]. Meat transportation was the business of contractor companies till 1940 after which corporate trucks were used for transportation purposes [15], see figure 7.

Being the very first modern slaughterhouse in Turkey, Sütlüce Slaughterhouse provided public service for many years during the Republican era [14]. Having functioned as the largest meat-butchering location of the city till 1985, Sütlüce Slaughterhouse terminated operations due to its heavy pollution in Haliç and started to operate only as a meat distribution centre. It is reported that in 1994 it functioned as some type of distribution centre in which meats transported via trucks from various parts of Anatolia were put up for sale [18]. Having lost its function in due course and its extreme polluting effect in Haliç, [22] Sütlüce Slaughterhouse was moved to Tuzla Aydınlıköy. Having remained inactive for a time, it was proposed that the slaughterhouse be changed into a cultural centre by 
the Istanbul Metropolitan Municipality. In 1988, its blueprint was prepared and the architectural project to transform the building into a cultural centre was approved by the Board of Project in 1989 [16]. Nine years after the project's endorsement, restoration works were initiated in 1998. Nonetheless, it was demolished on the basis that "Interior design of the historic building failed to match the construction program projected by the contractor" and it was replaced with a new building with no documentary value under the name of "Haliç Convention Centre". In this new building, the towers, pointed arches and blue tiles of the ice house - the most accentuated and remarkable part of slaughterhouse were reconstructed. Aside from that, the previous structure of the old slaughterhouse was alternated with large-mass concert and exhibition halls. Additionally, the original equipment of the structure such as its unique machinery plant could not be protected hence the world's foremost urban biological wastewater treatment facility was lost during the construction process [8].

\section{The impact of the industrialization process in Golden Horn on the city and conservation of industrial buildings}

The problem of conserving archaic industrial buildings has not been a longdebated issue in Turkey. It is thus safe to associate the earliest practices in this matter with the cleaning and rehabilitation projects of Haliç shores in Istanbul [18]. Hosting the Sütlüce Slaughterhouse, Haliç constantly remained on the agenda between 1950-2000 due to factory wastes, sewage and trash emptied onto the shore triggering bad odours and ecosystem problems [23]. That was the cause which motivated IBB (Istanbul Metropolitan Municipality) to launch rehabilitation projects and projects to re-functionalize industrial structures were initiated simultaneously.

During the administration of Istanbul Metropolitan Mayor Bedrettin Dalan (1984-1989), Haliç Land Use Plan was formed and a number of interventions, named "Dalan Operations" were initiated in the Haliç region. These interventions were in the form of removing the industrial zones on Haliç shores to be transformed into green fields open to public use. In practice, however, these interventions that were basically geared towards decentralizing industry and the central business area failed to meet the upper-scale plan decisions and triggered a number of demolitions that damaged the original identity of Haliç. It was witnessed that the so-called cleaning interventions of Haliç completely ignored the cultural assets that the region possessed for a long historical period and buildings that were inextricably intertwined with its unique identity were destroyed [24]. These projects prepared by Istanbul Metropolitan Mayor at the end of 1980s envisaged the destruction of some of the outdated manufacturing structures in Haliç, too. Following the registration of some of these structures formerly planned to be demolished, re-functioning projects gained impetus rather than demolition plans. One of the earliest re-functioning projects initiated in Haliç within this scope is the project of transforming Sütlüce Slaughterhouse into a cultural centre [18]. 


\section{Conclusion}

Despite the occasional measures enacted during the Ottoman rule to prohibit meat butchering performed under extremely unhealthy conditions, it is hard to claim that these measures proved to be effective in practice. Based on the early $20^{\text {th }}$ century positioning of slaughterhouses that had existed since the $17^{\text {th }}$ century in the Galata Tophane region, it has been identified that interconnected buildings to facilitate the meat butchering process used to exist close together. The functions of these buildings also displayed in the 1905-dated Goad insurance map gained a set of new functions and were united under 1923-dated Sütlüce Slaughterhouse. In the course of time European slaughterhouses were visited and examined and till the end of the 1920s, the places that formed this slaughterhouse were diversified. With the construction of Sütlüce Slaughterhouse, the butchering process started to be performed under more modern and hygienic conditions supervised by experts.

The original fittings, machinery, equipment and biological water treatment facilities of Sütlüce Slaughterhouse, which could only be erected under toilsome conditions extending over a long period, failed to be conserved to allegedly protect the design of the new interior space and comply with the program envisaged by the contractor. It got so much out of control that not only the fittings but the entire building itself was demolished and rebuilt based on that claim.

In Turkey, the concerns related to conserving industrial structures coincide with the end of the $20^{\text {th }}$ century, when the buildings on Haliç shores started to attract attention. Yet these concerns were, as evidenced in Sütlüce Slaughterhouse case, before making a connection with industrial heritage or industrial archaeology, had been associated with more general conservation causes as "Conserving Haliç's silhouette and cultural layers" [18] while in reality, any industrial building demands to be treated and conserved as an untouched unity with its original fittings, unique spaces and reflected effect on the silhouette of its city.

\section{References}

[1] Istanbul Encyclopaedia, Slaughterhouses, Istanbul Encyclopaedia from Yesterday to Today, History Wakf Publishing: Istanbul, 5, p. 446, 1994.

[2] Kucuk, S.G., Development of Karakoy-Kemeralti District, From Beginning of the 20th Century to Present, Conservation Problems and Suggestions, Unpublished Master Thesis, Istanbul Technical University: Istanbul, 2012.

[3] Kömürciyan, E.Ç., History of Istanbul: Istanbul in 17th Century. Eren Publishing: Istanbul, 1988.

[4] Cociffi, G., D’Ostoya Map, Atatürk Library Rare Collection: Istanbul, 1858-1860.

[5] Dagdelen I., Istanbul Insurance Maps of Charles Edouard Goad. Library and Museums Management Publishing: Istanbul, 2007.

[6] Dagdelen, I., Jacques Pervititch Insurance Maps. Turkey Economic and Social History Wakf Publishing: Istanbul, 1999.

[7] Nirven, S., Suat Nirven Map, Ataturk Library Rare Collection: Istanbul, 1948-1949. 
[8] Arkitera, http://v3.arkitera.com/h39465-sutluce-kultur-merkezibitti-mi.html

[9] İnciciyan, P. G., Istanbul in 18th Century, Fetih Publishing: Istanbul, 1956.

[10] M-Wiener. W., Istanbul Port from Byzantium to Ottoman, History Wakf Publishing: Istanbul, 2003.

[11] Environmental Issues which should be taken into consideration in Slaughtering Places, Environmental Impact Assessment Planning General Management, www.susuzoren.com/kurban.doc

[12] Williams, M. O., Turkey’s Invisible Parts, National Geographic Magazine Appendix, Istanbul, 2011, p. 46.

[13] Serefeddin, A., Karaagaç Slaughterhouse, Sabah Newspaper: Istanbul, 28 November 1919.

[14] Aydın, M., Debates over Sütlüce Slaughterhouse during the Armistice Period in Istanbul Press. The Journal of International Social Research, 3(14), pp. 100-106, 2010.

[15] İsmail, R., Is Slaughterhouse Required or not? Ikdam Newspaper: Istanbul, 1919.

[16] The facility leaving sweetbread sellers to present: Sütlüce Slaughterhouse, Industrialist Magazine, Online. http://www.sanayicidergisi.com/

[17] Golcu, B., The Regulations Related to Meat Inspection in Ottoman Empire. Veterinarians Association Magazine, 82(2), pp. 59-70, 2011.

[18] Incirlioğlu, G., Sütlüce Slaughterhouse, Arkitekt Magazine: Istanbul, 3, pp. 68-72, 1991.

[19] Batur, A., M. Vedad Tek, An Architect in the Track of His Identitiy, Yap1 Kredi Publishing: İstanbul, 2003.

[20] Kara, F. E., Sütlüce, Istanbul Encyclopaedia from Yesterday to Today, History Wakf Publishing: Istanbul, 7, pp. 117-119, 1994.

[21] Ataturk Library Photo Archive, Istanbul, Turkey.

[22] Arkitera, http://v3.arkitera.com/haberler/2002/11/11/sutluce.htm

[23] http://www.insanvecevre.com/halicteki-kirliligin-tarihcesi/

[24] Koseoglu, F. G., Haliç; location criteria and clustering aptitudes of cultural industries, the interaction between cultural industries and urban regeneration, Unpublished Master Thesis, İstanbul Technical University: İstanbul, 2010. 